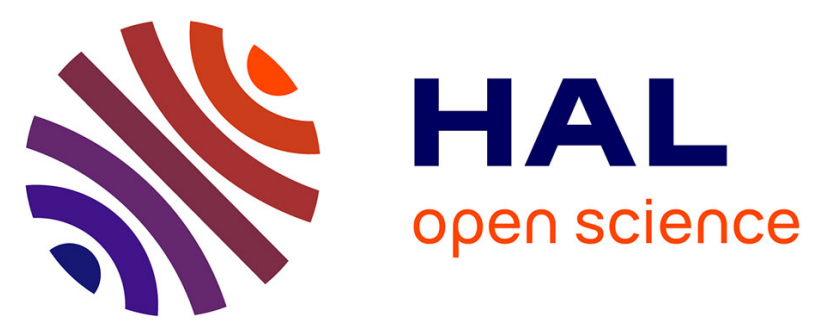

\title{
Alterations of fossil-bearing shale (Autun, France; Permian), part III: Framboidal pyrite and sulfur as the main cause of efflorescence
}

Giliane P. Odin, Oulfa P Belhadj, Thomas Cabaret, Eddy P Foy, Véronique Rouchon

\section{To cite this version:}

Giliane P. Odin, Oulfa P Belhadj, Thomas Cabaret, Eddy P Foy, Véronique Rouchon. Alterations of fossil-bearing shale (Autun, France; Permian), part III: Framboidal pyrite and sulfur as the main cause of efflorescence. Annales de Paléontologie, 2015, 10.1016/j.annpal.2016.01.001 . hal-01435260

\author{
HAL Id: hal-01435260 \\ https://hal.science/hal-01435260
}

Submitted on 13 Jan 2017

HAL is a multi-disciplinary open access archive for the deposit and dissemination of scientific research documents, whether they are published or not. The documents may come from teaching and research institutions in France or abroad, or from public or private research centers.
L'archive ouverte pluridisciplinaire HAL, est destinée au dépôt et à la diffusion de documents scientifiques de niveau recherche, publiés ou non, émanant des établissements d'enseignement et de recherche français ou étrangers, des laboratoires publics ou privés. 
Disponible en ligne sur

ScienceDirect

www.sciencedirect.com
Elsevier Masson France

www.em-consulte.com

Original article

\title{
Alterations of fossil-bearing shale (Autun, France; Permian), part III: Framboidal pyrite and sulfur as the main cause of efflorescence
}

\section{Dégradation de schistes argileux fossilifères (Bassin d'Autun, France, Permien), partie III : pyrite framboïdale et soufre identifiés comme cause principale des efflorescences}

\author{
Giliane P. Odin ${ }^{\mathrm{a}, \mathrm{b}}$, Oulfa Belhadj ${ }^{\mathrm{a}}$, Thomas Cabaret ${ }^{\mathrm{a}}$, Eddy Foy ${ }^{\mathrm{c}}$, Véronique Rouchon ${ }^{\mathrm{a}, *}$ \\ a Centre de Recherche sur la Conservation (CRC, USR3224), Sorbonne Universités, Muséum national d'Histoire naturelle, Ministère de la Culture et de la \\ Communication, CNRS, CP21, 36, rue Geoffroy-Saint-Hilaire, 75005 Paris, France \\ ${ }^{\mathrm{b}}$ Centre de Recherche sur la Paléobiodiversité et les Paléoenvironnements (CR2P, UMR7207), Sorbonne Universités, Muséum national d'Histoire naturelle, \\ Université Pierre-et-Marie-Curie, CNRS, 8, rue Buffon, 75005 Paris, France \\ ${ }^{c}$ LAPA-IRAMAT, NIMBE, CEA, CNRS, Université Paris-Saclay, CEA Saclay, 91191 Gif-sur-Yvette cedex, France
}

\section{A R T I C L E I N F O}

\section{Article history:}

Received 7 October 2015

Accepted 26 November 2015

Available online $\mathrm{xxx}$

\section{Keywords:}

Fossil-bearing shale

Iron sulfate

Framboidal pyrite

Oxidation

Maceral

Autun Basin

Artificial ageing

\begin{abstract}
A B S T R A C T
Fossil-bearing shale specimens that include sulfides are chemically reactive and sometimes also mechanically fragile. This decay is provoked by iron sulfate efflorescence resulting from the oxidation of sulfide compounds. The processes underlying these degradations are poorly known, thus impeding the elaboration of curative or preventive treatments. The present contribution aims to identify the origin of museum specimen alterations. It focuses on the Flouest collection housed at the Muséum national d'Histoire naturelle (MNHN, Paris, France) and originating from the Autun Basin (Saône-et-Loire, France; Permian). To evaluate the alteration of MNHN specimens, it appeared necessary to compare their composition with that of unaltered shale so as to identify chemical changes occurring during ageing. Therefore new material was collected in the Autun Basin, among others on the locality of Muse that corresponds to the same lithostratigraphic unit than that of the MNHN specimens. This work is divided in three parts. The two first, presented elsewhere, deal with the composition of the shale matrices and led to the conclusion that these matrices could not account for the large iron(II) sulfate efflorescence provoking damage on the MNHN specimens. The last part of this work, presented here, focus on artificial ageing experiments performed on new shale material. Most of the alterations observed on artificially aged samples correspond to dispersed crystals of calcium sulfate (gypsum). Similar crystals may be found on MNHN specimens, but they are relatively few and sporadically distributed. They are thus considered as damage of secondary importance with respect to iron sulfate efflorescence. These latter could be reproduced on three samples only (upon the 142 aged samples). They were also found on a coprolite and on a wood remain that had got severely damaged in ambient conditions within a few months after their excavation. On all these samples iron sulfate had grown on brownish layers consisting in crystals of framboidal pyrite ( 1 to $3 \mu \mathrm{m}$ ) and eventually sulfur (20 to $50 \mu \mathrm{m}$ ). These brownish layers are associated to thin maceral layers probably because of bacterial activity: during fossil diagenesis, bacteria need organic matter for their metabolism to produce hydrogen sulfide, a precursor of sedimentary pyrite formation. Most of the damaged specimens of the Flouest collection show as well a thin maceral layer nearby iron(II) sulfate efflorescence. On one of them, this layer is particularly thick. It corresponds to vitrinite and shows in some areas a brownish aspect. The topology of this surface (observed with scanning electron microscopy) shows numerous small holes $(<2 \mu \mathrm{m})$ and large holes $(10-20 \mu \mathrm{m})$. This morphology is compatible with a former occurrence of isolated grains and aggregates of framboidal pyrite. These observations suggest that iron sulfate efflorescence was provoked by the
\end{abstract}

\footnotetext{
* Corresponding author.

E-mail addresses: giliane.odin@mnhn.fr(G.P.Odin), belhadj@mnhn.fr(O.Belhadj),tcabaret@yahoo.fr (T.Cabaret),eddy.foy@cea.fr (E. Foy),rouchon@mnhn.fr(V.Rouchon).
} 
oxidation of framboidal pyrite forming deposits on maceral layers. Because of their brownish aspect, they can easily go unnoticed by naked eye. This work will also help to improve visual assessment of currently collected fossils so as to identify the most reactive ones.

(c) 2016 Elsevier Masson SAS. All rights reserved.

Mots clés :

Schistes argileux fossilifères

Sulfate de fer

Pyrite framboïdale

Oxydation

Macéraux

Bassin d'Autun

Vieillissement artificiel

\section{R É S U M É}

Les schistes argileux fossilifères contenant des sulfures sont chimiquement réactifs et peuvent également devenir fragiles mécaniquement. Ces dégradations sont souvent liées à des efflorescences de sulfates de fer résultant de l'oxydation de produits sulfurés. Les mécanismes sous-jacents à ces dégradations sont généralement peu connus, ce qui limite l'élaboration de traitements curatifs ou préventifs. Ce travail vise à identifier l'origine des dégradations observées sur les spécimens de collections, en particulier ceux de la collection Flouest qui provient du bassin d'Autun (Saône-et-Loire, France, Permien) et est aujourd'hui conservée au Muséum national d'Histoire naturelle (MNHN). Pour évaluer la dégradation des spécimens MNHN, il est apparu nécessaire de comparer leur composition à celles de schistes argileux non altérés, de manière à mettre en évidence les changements de composition chimique. C'est pourquoi du matériel neuf a été prélevé dans le bassin d'Autun, entre autres sur le site de Muse qui correspond à la même unité lithostratigraphique que celle des spécimens MNHN. Ce matériel a été, au besoin, vieilli artificiellement. Ce travail est organisé en trois parties. Les deux premières traitent de la composition des matrices de schiste argileux et amènent à conclure que ces matrices ne sont pas à l'origine des larges efflorescences de sulfate de fer(II) qui endommagent les spécimens MNHN. La dernière partie de ce travail, présentée ici, porte sur les expériences de vieillissement artificiel menées sur des schistes nouvellement prélevés. La plupart des altérations observées sur les échantillons vieillis artificiellement correspondent à des cristaux dispersés de sulfate de calcium (gypse). Des cristaux similaires sont parfois trouvés sur les spécimens MNHN, mais ils sont relativement peu nombreux et distribués de manière sporadique. Ils sont donc considérés comme des dommages de seconde importance en comparaison des efflorescences de sulfates de fer. Ces derniers ont pu être reproduits sur trois échantillons seulement (parmi 142 échantillons vieillis artificiellement). Ils ont également été trouvés sur un coprolithe et un échantillon de bois fossilisé sévèrement dégradés en conditions ambiantes dans les quelques mois ayant suivi leur excavation. Pour tous ces échantillons, les sulfates de fer se sont formés sur une couche brunâtre composée de pyrite framboïdale $(1 \mathrm{à} 3 \mu \mathrm{m})$ et, dans certains cas, de soufre $(20$ à $50 \mu \mathrm{m})$. Ces couches brunâtres sont systématiquement associées à une couche de macéral, c'est-à-dire de matière organique. Celle-ci est nécessaire aux bactéries pour produire du sulfure d'hydrogène, précurseur à la formation de pyrite sédimentaire lors de la diagenèse. La plupart des spécimens endommagés de la collection Flouest montrent également une fine couche de macéral à proximité des efflorescences de sulfate de fer(II). Sur l'un d'entre eux, cette couche est particulièrement épaisse. Elle correspond à de la vitrinite et montre en certains endroits un aspect brunâtre. La topologie de cette surface (observée en microscopie électronique à balayage) montre de nombreuses petites cavités $(<2 \mu \mathrm{m})$ et des cavités plus larges $(10-20 \mu \mathrm{m})$. Cette morphologie est compatible avec l'existence antérieure de grains isolés et d'agrégats de pyrite framboïdale. Ces observations suggèrent que les efflorescences de sulfate de fer observées sur les spécimens MNHN ont été provoquées par l'oxydation de fines couches de pyrite framboïdale déposées sur des couches de macéraux. Elles peuvent, de par leur aspect brunâtre, passer facilement inaperçues. Ce travail permet donc d'améliorer l'examen visuel des fossiles en cours de prélèvement sur le bassin d'Autun et d'identifier plus rapidement les spécimens potentiellement réactifs.

@ 2016 Elsevier Masson SAS. Tous droits réservés.

\section{Introduction}

The paleontological collections of the Muséum national d'Histoire naturelle (MNHN, Paris, France) house several shale specimens that are severely damaged by sulfate efflorescence. The Flouest collection is particularly emblematic. It was collected during the 19th century in the "Autunian" of the Autun Basin (Saône-et-Loire, France; Permian) and comprises several highly damaged specimens housed in the same drawer and in a room without air conditioning (M17, Adolphe Brogniart's room, paleobotanical building, MNHN). The conservation report (Rouchon et al., 2012) showed that most of the damage consists in sulfate efflorescence growth outlining the fossil. This efflorescence is mostly composed of iron(II) sulfates (rozenite, $\mathrm{Fe}^{\mathrm{II}} \mathrm{SO}_{4} \cdot 4 \mathrm{H}_{2} \mathrm{O}$ and szomolnokite, $\mathrm{Fe}^{\mathrm{II}} \mathrm{SO}_{4} \cdot \mathrm{H}_{2} \mathrm{O}$ ) with possibly a minor proportion of iron(III) sulfates. It compromises the fossil legibility and the integrity of the matrix. Additionally, it is often observed that sulfate efflorescence growth had occurred nearby maceral layers.

This work was undertaken in order to better understand the cause of these degradations and in particular to identify the reactive species that were initially present before the specimens got deteriorated. It more specifically focusses on the above-mentioned Flouest collection. As degradation products mainly consist of sulfates, the damage is obviously caused by the oxidation of reduced sulfur compounds. The problem consists here in identifying these compounds. Pyrite is the most obvious candidate. This iron sulfide of chemical composition $\mathrm{FeS}_{2}$ is well known for its poor stability in humid conditions. Its oxidation motivated intensive researches (Chandra and Gerson, 2010; Heidel and Tichomirowa, 2011; Murphy and Strongin, 2009; Rimstidt and Vaughan, 2003; Rosso and Vaughan, 2006; Schoonen et al., 2010). It has in particular been shown that pyrite could not only be oxidized by oxygen, but also by water and that the oxidation is drastically enhanced by combined exposure to both.

Pyrite is not the only sulfide that could be incriminated. Other iron sulfides such as marcasite, pyrrhotite, greigite, or mackinawite are also good candidates. Moreover, the Autun basin shale was mined in the past to produce oil and ammonium sulfate. It contains a significant proportion of organic matter, and in particular organic sulfides.

This work is organized in three parts. The first two are dedicated to the characterization of sulfur- and iron-bearing compounds 
present in the shale matrix (Odin et al., 2015a, 2015b) and led to the conclusion that these compounds could not account for the large efflorescence noticed nearby the fossil line.

The third part of this work, presented in this article, focus on the ageing of newly collected shale samples originating from similar lithographic layers. It aims to reproduce on this new material the damage observed on MNHN specimens. This could be achieved on some samples that were afterward analyzed in order to identify the compounds responsible for the decay. For this purpose, Raman microspectroscopy and X-ray micro-diffraction were used for phase identification. These analyzes were usefully completed by scanning electron microscopy imaging coupled with an Energy Dispersive X-ray Spectrometer(SEM/EDS) for morphological observations and semi-quantitative elemental analysis.

\section{Samples and geological settings}

\subsection{Geological settings}

\subsubsection{The locality of Muse}

In order to reproduce damage in laboratory conditions, it was chosen to sample new shale material in the outcrop of Muse (Dracy Saint Loup, Saône-et-Loire, France) that comprises several layers, the most famous of which being commonly called the "Muse fish layer" and hereafter referred to as Muse FL. The motivation of this choice are fully explained elsewhere (Odin et al., 2015b). This layer (Late Carboniferous - Lower Permian of the Autun Basin) is located at the base of the bedding of Muse above a pebble layer (sandstones of Lally). Layers situated approx. 1-2 meters above, hereafter referred to as Muse layers, are also of paleontological interest: they mainly consist of plants (both palynomorphs and macroflora), "cockroachoid" insects (stem-Dictyoptera) and crustaceans (Ostracods).

\subsubsection{The locality of Surmoulin}

In a previous study (Odin et al., 2014), samples taken from the Surmoulin layer (outcrop of Surmoulin, Dracy Saint Loup, Saôneet-Loire, France) gave, upon artificial ageing, rise to abundant calcium sulfate efflorescence and substantial mechanical damage. New material from this outcrop was also considered and hereafter referred to as Surmoulin.

\subsection{Samples used for artificial ageing experiments}

Muse FL, Muse and Surmoulin shale samples showed after splitting some orange rusted-like plans confirming that they were at least partially exposed to weathering. As reported by others authors (Tuttle et al., 2014), these rust deposits occurred laterally, depending on the shale bedding plans. This is in-line with previous work (Odin et al., 2015a, 2015b) showing that (i) the shale was transversally poorly permeable to water and impermeable to air and (ii) sulfur was mostly present as organic and inorganic sulfide. Also black shale samples were selected for artificial ageing, as they were believed to have been relatively spared from weathering.

In order to limit drying and oxidation after excavation, they were housed in air and water vapor tight plastic bags $\left(\mathrm{ESCAL}^{\odot}{ }^{\circledR}\right.$, Long Life for Art, Germany) with oxygen scavenger bags $\left(\right.$ ATCO $^{\odot}$ FTM, Long Life for Art, Germany).

\section{3. "Naturally" damaged samples}

"Naturally" damaged samples deal with samples that were stored in ambient conditions and on which post excavation damages were observed.

\subsubsection{The specimen MNHN.FR.6889 as a model of damaged specimen}

The specimen MNHN.FR.6889 (hereafter referred to as 6889) from the Flouest collection was chosen as a model because it is a typical case of degradation observed in that collection (Fig. 1).

This specimen comprises a 0.5 to $1 \mathrm{~cm}$ thick layer of vitrinite supported by the shale. It is severely damaged by crystalline efflorescence related to iron(II) sulfates (rozenite, $\mathrm{Fe}^{\mathrm{II}} \mathrm{SO}_{4} \cdot 4 \mathrm{H}_{2} \mathrm{O}$ and szomolnokite, $\mathrm{Fe}^{\mathrm{II}} \mathrm{SO}_{4} \cdot \mathrm{H}_{2} \mathrm{O}$ ) with some small amount of ferricopiapite ( $\mathrm{Fe}^{\mathrm{III}} 2 / 3 \mathrm{Fe}_{4} \mathrm{III}_{4}\left(\mathrm{SO}_{4}\right)_{6}(\mathrm{OH})_{2} \cdot 2 \mathrm{H}_{2} \mathrm{O}$ ) (Rouchon et al., 2012). Visual assessment (using macro-pictures) showed no noticeable evolution of efflorescence within a period of 3 years, meaning that the specimen is relatively stable.

The shale fraction of this specimen was analyzed (Odin et al., 2015a, 2015b), showing that matrix-sulfur is almost entirely oxidized as sulfate (gypsum and belonging to jarosite group). In contrast, vitrinite is not much affected by oxidation. In this material, the speciation of sulfur mainly corresponds to organic sulfides. This is probably because vitrinite shows no porosity, meaning that sulfur is not accessible to water and oxygen. Another reason for the choice of specimen 6889 lies in the fact that it presents a brownish layer (Fig. 1b) that has visually some similarities with the brownish layer of the Copro and Wood samples depicted hereafter.

\subsubsection{Damaged wood}

Some Muse FL slabs were wrapped in a plastic film and let for a slow drying in an air-conditioned rooms $\left(18.5^{\circ} \mathrm{C} \pm 3.5^{\circ} \mathrm{C}, 45 \% \pm 5 \%\right.$ $\mathrm{RH})$. They were split 18 months after their excavation and delivered an interesting sample of wood, hereafter called Wood, which was highly damaged by white and yellow efflorescence (Fig. 2). The splitting revealed a cleavage plan that was entirely covered with rust-like deposits meaning that it was obviously subjected to weathering. The sample has a complex structure: the inner part looks like a maceral (Fig. 2b and c) while the outer part is made of a brown layer, juxtaposing large pyrite-like crystals (Fig. 2d). Efflorescence concentrates on the surface of the wood and on the brown

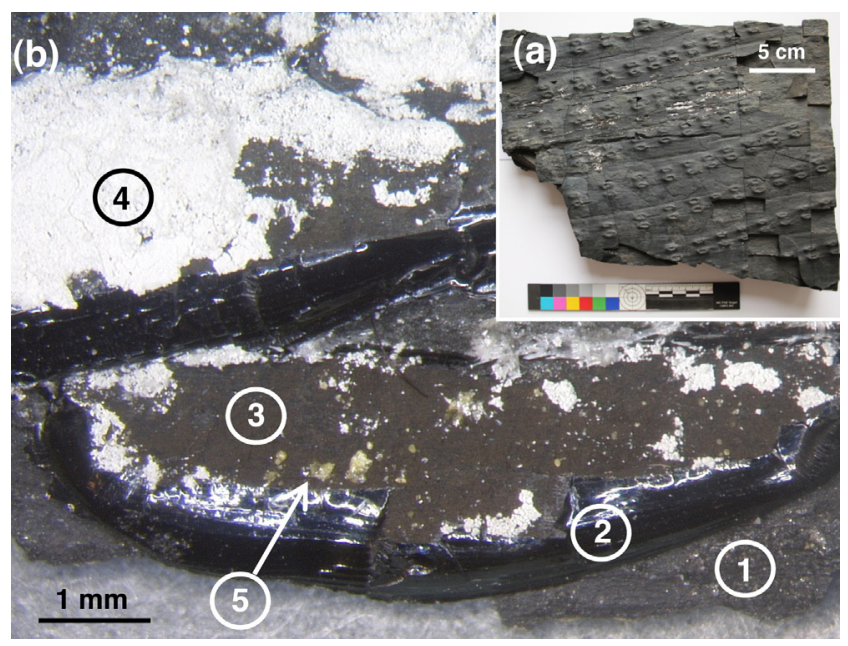

Fig. 1. General view and detail of specimen 6889 (MNHN.FR.6889). This specimen is constituted of a shale layer (1) covered by a layer of vitrinite (2) that presents in some areas a brownish aspect (3). Iron sulfate efflorescence is largely present at the interface of these two layers. It is composed of a major amount of white iron(II) sulfate (rozenite and szomolnokite) (4) and a minor amount of yellow iron (III) sulfate (ferricopiapite) (5).

Vue générale et détail du spécimen 6889 (MNHN.FR.6889). Ce spécimen est constitué d'une couche de schiste argileux (1) couvert par une couche de vitrinite (2) qui présente en certains endroits un aspect brunâtre (3). Des efflorescences de sulfates de fer sont largement présentes à l'interface de ces deux couches. Elles se composent en majeure partie de sulfates de fer(II) blancs (rozénite et szomolnokite)(4) et d'une fraction mineure d'un sulfate de fer(III) jaune (ferricopiapite) (5). 

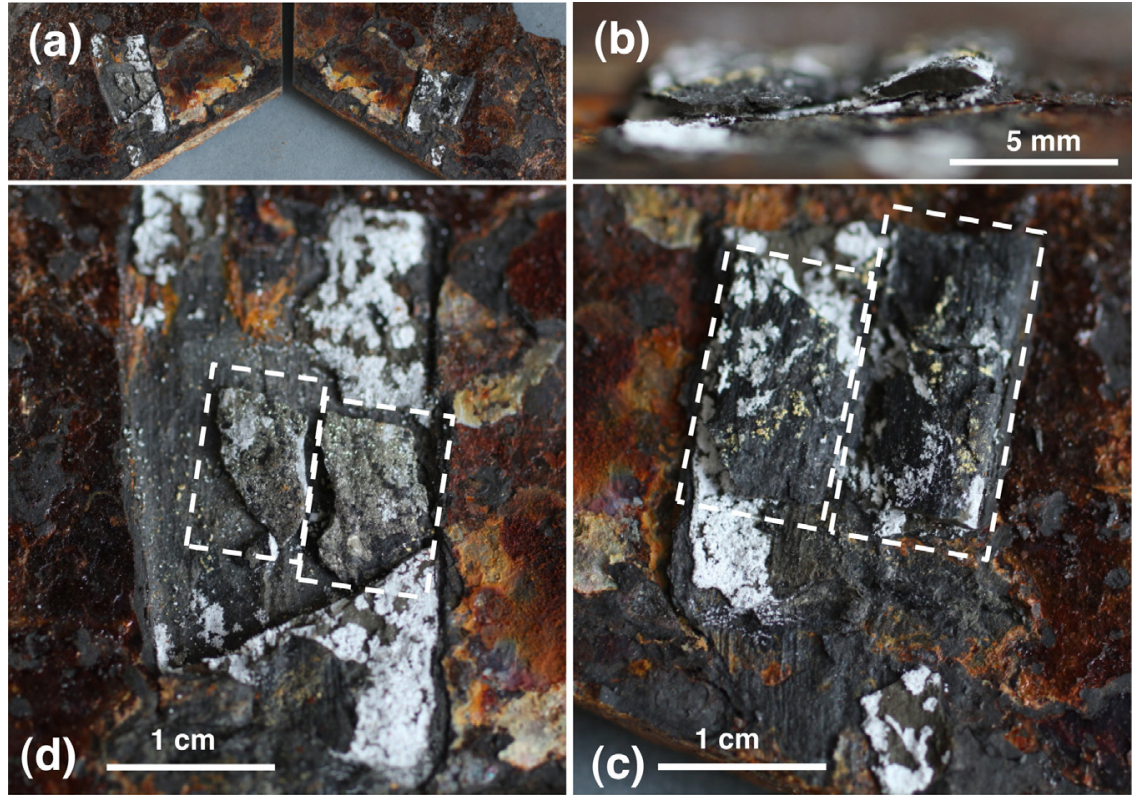

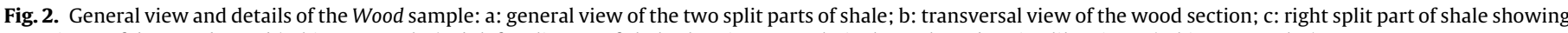
two pieces of damaged wood (white rectangles); d: left split part of shale showing two relatively unaltered pyrite-like pieces (white rectangles).

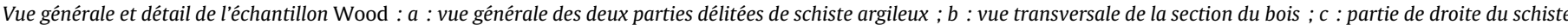

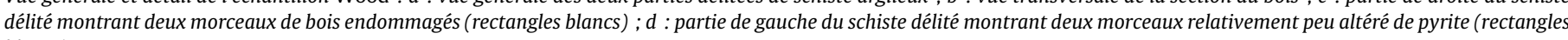
blancs).

layer (Fig. 2b and c) whereas pyrite-like crystals appear still shiny and seem to be relatively unaltered.

\subsubsection{Damaged coprolite}

Some additional slabs were sampled in Muse layers, approx. 1-2 meters above the Muse FL, and were kept in an air-conditioned room $\left(21^{\circ} \mathrm{C} \pm 2{ }^{\circ} \mathrm{C}, 50 \% \pm 10 \% \mathrm{RH}\right)$. One of these delivered a coprolite (hereafter referred to as Copro) that had got severely damaged within a couple of months. When sampled, the slab had already some yellow efflorescence probably due to weathering. Yet the coprolite was well preserved and the surrounding shale had a black aspect. After a couple of months, the coprolite seemed to have "exploded" because of efflorescence growth (Fig. 3a). A closer look at broken pieces showed that white crystal were growing on a brownish layer covering thin layers of maceral similar to that of the Wood sample (Fig. 3b).

\section{Analytical methods}

\subsection{Artificial ageing and visual assessment}

Artificial ageing at controlled temperature and relative humidity $(\mathrm{RH})$ was performed in an attempt to reproduce on newly excavated shale the damage observed on collection specimens. It was already experimented in previous study (Odin et al., 2014) on shale samples taken from seven different outcroups of the Autun basin. These were exposed for 15 weeks at $50 \%$ of relative humidity (RH) and at temperature $40^{\circ} \mathrm{C}$ and $90^{\circ} \mathrm{C}$. Sets of eight samples were constituted for each combination of layer/ageing condition in order to test the reproducibility of the experiment. Among these eight samples, a great discrepancy of behaviors was often observed that is probably attributable to shale heterogeneities. It was therefore decided to pursue these experiments with the same experimental setup, choosing a restricted number of layers (Muse FL and Surmoulin) and selecting larger sample sets (16 to 20 for each combination of layer/ageing condition). Higher humidity conditions ( $80 \% \mathrm{RH})$ were additionally tested using another silica gel (Silikagel M, Long
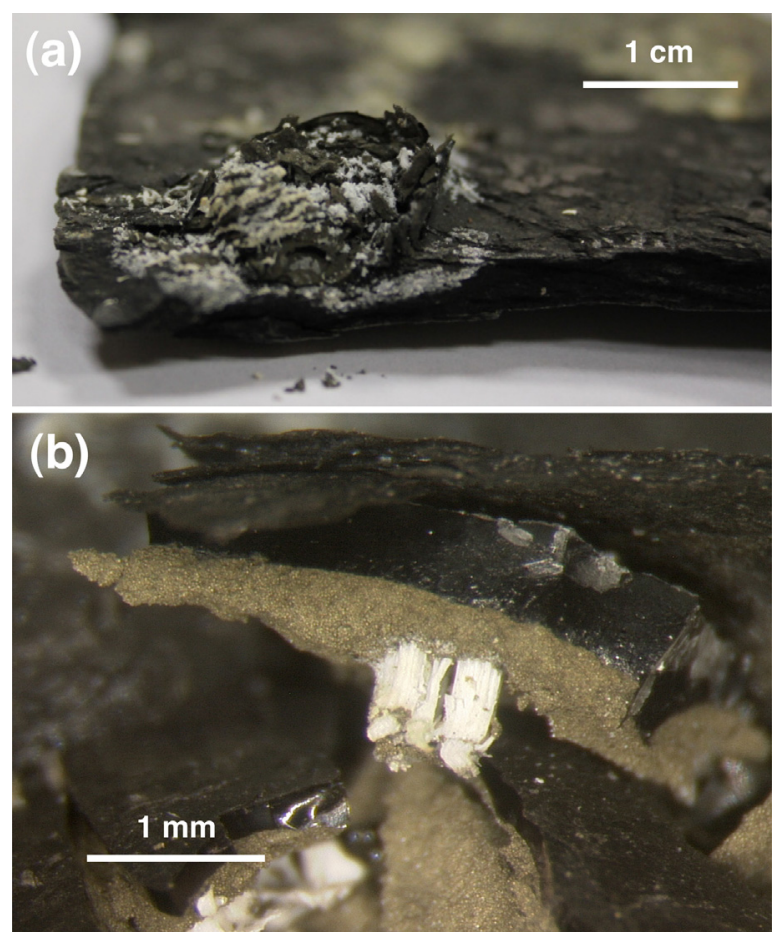

Fig. 3. General view and details of the Copro sample: a: general view of the damaged coprolite situated on the edge of the slab; b: detail showing white crystals growing upon a brownish deposit fixed to a maceral layer.

Vue générale et détail de l'échantillon Copro : a : vue générale du coprolithe situé sur le bord de la plaque de schiste $; b$ : détail montrant la croissance de cristaux blancs un dépôt brunâtre fixé à la couche de macéral.

Life for Art, Germany) as it was shown that they were boosting the oxidation of sulfides (Odin et al., 2015b).

Two campaigns of ageing, 15 weeks each and respectively referred to as ageing 1 and ageing 2 were consecutively undertaken (Table 1). Visible changes during artificial ageing were evaluated 
Table 1

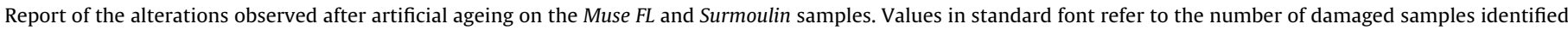

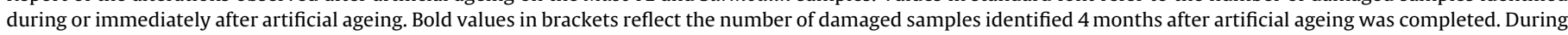
this period, samples were kept in ambient conditions without particular cautions.

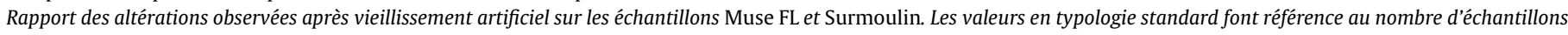

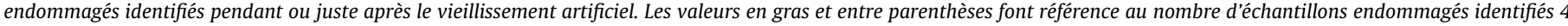
mois après la procédure de vieillissement artificiel. Au cours de cette période les échantillons ont été conservés en conditions ambiantes sans précaution particulière.

\begin{tabular}{|c|c|c|c|c|c|c|c|c|}
\hline \multirow[b]{3}{*}{ Relative Humidity (\% RH) } & \multicolumn{4}{|c|}{ Ageing 1} & \multicolumn{4}{|c|}{ Ageing 2} \\
\hline & \multicolumn{4}{|c|}{ Muse FL } & \multicolumn{2}{|c|}{ Muse FL } & \multicolumn{2}{|c|}{ Surmoulin } \\
\hline & 50 & 50 & 80 & 80 & 80 & 80 & 80 & 80 \\
\hline Temperature of ageing $\left({ }^{\circ} \mathrm{C}\right)$ & 40 & 90 & 40 & 90 & 40 & 90 & 40 & 90 \\
\hline Efflorescence & $4(6)$ & $6(8)$ & $5(11)$ & $15(\mathbf{1 6})$ & 0 & 18 & 0 & 17 \\
\hline Mechanical damage & 3 & 3 & 2 & 5 & 2 & 3 & 2 & 1 \\
\hline No damage & 9 & 9 & 10 & 1 & 18 & 1 & 18 & 3 \\
\hline Efflorescence and mechanical damage & 0 & 2 & 1 & 5 & 0 & 2 & 0 & 1 \\
\hline Total number of samples & 16 & 16 & 16 & 16 & 20 & 20 & 20 & 20 \\
\hline
\end{tabular}

for each sample with macro-pictures taken with a digital camera placed on top of a LED light booth, $6500 \mathrm{~K}$ (Dome 130, Lightune, France). The comparison between pictures taken before and after ageing enabled the identification of changes. This visual assessment allowed for pinpointing the most obvious damages.

\subsection{Raman microspectroscopy}

Raman microspectroscopy (inVia, Renishaw, UK; $532 \mathrm{~nm}, 0.5$ to $2.5 \mathrm{~mW}, 50 \times$ objective) is a powerful tool for a fast identification of many sulfates and sulfides species. Micro samples taken from damaged areas were analyzed in a similar way as previous work (Rouchon et al., 2012). When sampling was not possible, analyzes were conducted directly on the surface of interest.

\subsection{X-ray micro-diffraction (XRD)}

As some sulfide species, such as pyrrhotite, yield no Raman spectra (Mernagh and Trudu, 1993), it appeared necessary to complete Raman analyses mentioned above with X-ray micro-diffraction (XRD), using a molybdenum anode $(\lambda$ : $0.70932 \AA)$. The X-ray beam was focused in two different experimental setups designed for different sample morphologies. In the first one, the beam is focused up to $50 \times 30 \mu \mathrm{m}^{2}$ with a photon flux of $10^{6} \mathrm{phs}^{-1}$. It impinges the sample surface with an incident angle of $5^{\circ}$, yielding a sample spot size of approx. $600 \times 30 \mu \mathrm{m}^{2}$. In the second experimental setup, the beam is perpendicular to the sample surface and reaches a nominal size of $100 \times 100 \mu \mathrm{m}^{2}$ with a photon flux of $20 \times 10^{6} \mathrm{phs}^{-1}$. In both cases, patterns were collected in transmission mode downstream the sample with a two-dimensional image plate detector. Classical $I=f(2 \theta)$ patterns were obtained after circular integration of the diffracted image using FIT2D program (Hammersley et al., 1996). All data were treated with the EVA software and minerals were identified using the PDF database of the Joint Committee Powder Diffraction Standard.

\subsection{Scanning Electron Microscopy/Energy Dispersive X-ray Spectroscopy (SEM/EDS)}

Areas of interest were examined with SEM/EDS in order to document the morphology and elemental contents of sedimentary deposits. Measurements were conducted without any specific sample preparation with a low vacuum scanning electron microscope (Hitachi Su 3500) coupled with an X-ray probe. Mappings were recorded with the following experimental parameters: accelerating voltage, 15 to $20 \mathrm{kV}$; pressure, $70-90 \mathrm{~Pa}$; working distance, 5 to $8 \mathrm{~mm}$. Elemental data were treated with the NSS software (Thermo Scientific, USA). The detection of oxygen in sulfur bearing phases was a key element to distinguish reduced species (typically sulfides) from oxidized ones (typically sulfates). The reliability of quantitative elemental analysis was additionally tested on pyrite and pyrrhotite model compounds, leading to an estimation of atomic percentage $S: F e$ ratios of $1.7 \pm 0.2$ for pyrite and $1.0 \pm 0.2$ for pyrrhotite.

\section{Results}

\subsection{Artificial ageing of newly excavated shale}

\subsubsection{Visual assessment immediately after ageing}

In the ageing 1 campaign, different combinations of temperature $\left(40-90^{\circ} \mathrm{C}\right)$ and relative humidity $(50-80 \%)$ were tested on a set of $64(4 \times 16)$ samples of Muse FL. The visual assessment was first performed immediately after the 15 weeks of ageing (Table 1 , column 2 to 5 , values in standard font). Ageing at low humidity or (exhaustive) low temperature (Table 1, columns 2, 3 and 4) affected a minority of samples (crystal growth was observed on 4 to 6 samples upon 16 and mechanical damage on 2 to 3 samples upon 16). The combined use of high humidity conditions and high temperature $\left(80 \%-90^{\circ} \mathrm{C}\right)$ significantly boosted crystal growth, as 15 samples upon 16 were affected by efflorescence (Table 1 , column 5). It however did not have a high impact on mechanical damage.

In order to verify the reproducibility of the ageing process, a second campaign of artificial ageing (ageing 2) was undertaken on two new sets of 20 samples originating from Muse FL and Surmoulin. These were aged at high humidity ( $80 \% \mathrm{RH})$ and two temperature conditions $\left(40^{\circ} \mathrm{C}\right.$ and $\left.90^{\circ} \mathrm{C}\right)$. Similar results were obtained (Table 1 , column 6 to 9 ). When ageing was performed at low temperature $\left(40^{\circ} \mathrm{C}\right)$, no efflorescence was observed and few samples were affected by mechanical damaged ( 4 upon a total of 40 ). Increasing the temperature up to $90^{\circ} \mathrm{C}$ resulted in a large number of samples affected by efflorescence ( 35 samples upon 40 ) but seemed to have no significant impact on cracks and losses.

\subsubsection{Post-ageing visual assessment}

After the ageing 1 campaign, the samples were placed in an office room without air conditioning (temperature varying between $18^{\circ} \mathrm{C}$ and $22^{\circ} \mathrm{C}$, humidity conditions below $50 \% \mathrm{RH}$ ). Approximately 4 months after, the visual assessment was reiterated showing a significant increase of the number of samples concerned by efflorescence (Table 1 , bold values in brackets). On these samples, this damage was probably initiated during artificial ageing, yet to a level that was imperceptible for naked eye. It continued afterward and then became perceptible.

\subsubsection{Raman analyses of efflorescence and selection of new samples}

Raman microspectroscopy was used to probe the crystalline nature of efflorescence observed on the samples of ageing 1 and 

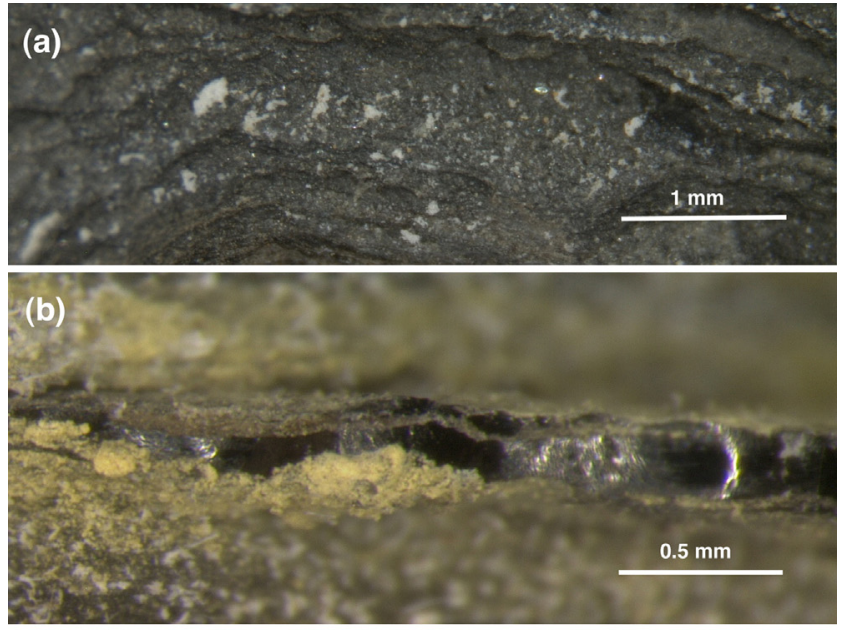

(c)

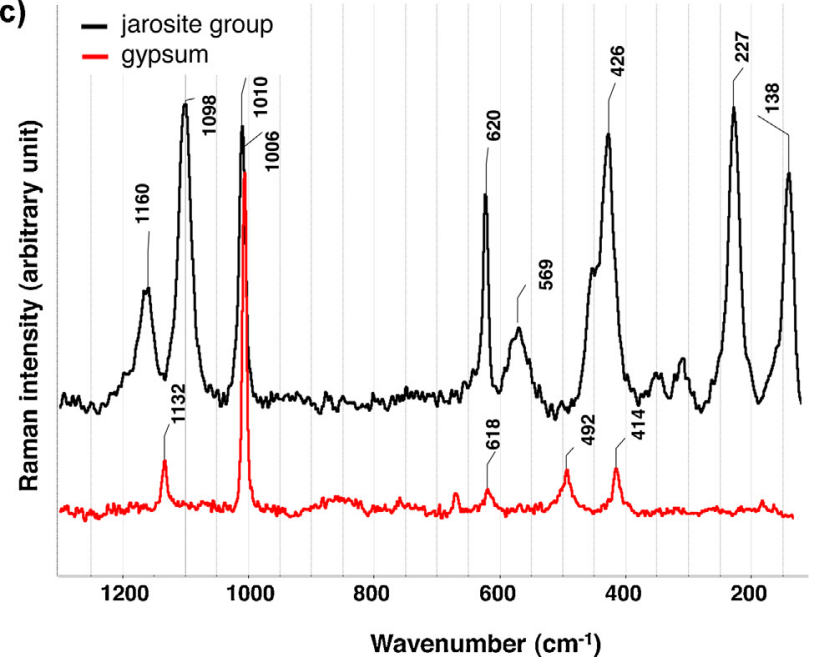

Fig. 4. Examples of crystalline efflorescence occurring on artificially aged samples: a: typical efflorescence of gypsum; b: edge of sample B showing yellow efflorescence of jarosite growing in the proximity of a maceral layer and white crystals corresponding to gypsum; c: Raman signature of the gypsum and jarosite crystals found on sample B.

Exemples d'efflorescences cristallines apparaissant sur les échantillons vieillis : a : efflorescences typiques de gypse ; $b$ : bord de l'échantillon $B$ montrant des efflorescences jaunes de jarosite croissant à proximité d'une couche de macéral et des cristaux blancs correspondant à du gypse ; $c$ : signature Raman des cristaux de gypse et de jarosite trouvés sur l'échantillon $B$.

ageing 2 campaigns. These samples were dispatched in two groups. In the first group, efflorescence was limited to gypsum $\left(\mathrm{CaSO}_{4} \cdot 2 \mathrm{H}_{2} \mathrm{O}\right)$ growth sporadically spread on the shale surface (Fig. 4a). This group gathered the majority of samples and in particular, all Surmoulin samples.

The second group was by far the most interesting although it gathered 3 samples only, all originating from Muse FL and hereafter referred to as B, C and D. These samples had in common to show on their edge white to yellow spots of iron sulfate efflorescence located nearby a thin maceral layer (Fig. 4b). White efflorescence was mainly related to rozenite and szomolnokite while yellow efflorescence belonged to the jarosite group (Fig. 4c). On sample B that was the most damaged, gypsum growth was also observed on the sample edge, yet it was not correlated to the vitrine layer (Fig. 4b and c). This feature is similar to what was observed on damaged collection specimens on which iron sulfate efflorescence was mainly occurring nearby vitrinite (Odin et al., 2015b). The characterization of samples B, C and D was therefore more deeply investigated.

\subsubsection{Micro analysis of samples $B, C$ and $D$.}

A careful examination of $B, C$ and $D$ sample edges revealed that an additional brownish layer was juxtaposing the maceral layer (Figs. 4b and 5a, b). This brownish layer was more or less covered with iron sulfates, which seriously limited its analysis by Raman micro spectrometry. In particular, no Raman signature characteristic of reduced sulfur compounds was isolated on sample B that was by far the most damaged of the three samples. On samples $C$ and $\mathrm{D}$ that were in better condition, pyrite was evidenced by Raman microspectroscopy (Table 2 ). The sample $C$ could be additionally analyzed by micro XRD analysis because it presented a geometry that was compatible with the experimental setup. These analyses confirmed the occurrence of pyrite and no additional sulfide phase was detected.

SEM/EDS imaging usefully completed this approach, showing, for the brownish layer of samples $C$ and $D$, a similar morphology (Fig. 5b and c), almost entirely constituted of framboidal pyrite with grain size ranging from 1 to $3 \mu \mathrm{m}$.

\subsection{Micro analysis of the "naturally" damaged samples}

\subsubsection{Micro analysis of Wood sample}

Crystalline efflorescence, characterized by Raman microspectroscopy, was exclusively composed of iron sulfates. Iron(II) sulfates were abundant and present as rozenite, szomolnokite and halotrichite $\left(\mathrm{Fe}^{\mathrm{II}} \mathrm{Al}_{2}\left(\mathrm{SO}_{4}\right)_{4} \cdot 22 \mathrm{H}_{2} \mathrm{O}\right)$. Some amounts of iron(III) sulfates belonging to the jarosite group were also detected.

The shiny crystals (Fig. 2d, white rectangles) were iron sulfide, identified as being exclusively pyrite but partially altered with iron sulfate (Fig. 6d). These large crystals showed no framboidal structure.

Additionally, framboidal pyrite was found on the brownish layer that partially covers the two pieces of wood (Fig. 2c, white rectangles and Fig. $6 a-c)$, yet in combination with isolated sulfur grains (Fig. 6b). No additional crystalline sulphide was detected on this layer by micro XRD analysis.

\subsubsection{Micro analysis of the Copro sample}

Crystalline efflorescence, characterized by Raman microspectroscopy, was, inside the coprolite, exclusively composed of rozenite when it was first analyzed. It had been growing perpendicular to the brownish layer (Fig. 3b), and probably took a large part in the mechanical stress that provoked the coprolite breakdown. Halotrichite and alunogen $\left(\left(\mathrm{Al}\left(\mathrm{H}_{2} \mathrm{O}\right)_{6}\right)_{2}\left(\mathrm{SO}_{4}\right)_{3} \cdot 5 \mathrm{H}_{2} \mathrm{O}\right)$ were as well detected, yet exclusively on the external face of the shale around the coprolite. Szomolnokite was also detected, yet several months after the first analyzes. It probably corresponds to a secondary phase resulting from the dehydration of rozenite.

The maceral present in the coprolite was identified as vitrinite (FTIR measurements, not shown). It was covered with a brownish/shiny layer (Figs. 3b and 7a), in which pyrite and sulfur were additionally detected by Raman microspectroscopy (Fig. 7b and d). Micro XRD confirmed the occurrence of pyrite and rozenite. No additional crystalline phase was detected.

SEM/EDS analysis showed that pyrite was, here again, framboidal (Fig. $7 \mathrm{~b}$ and c). It is organized in micro-crystals ( 1 to $3 \mu \mathrm{m}$ ) surrounding isolated sulfur crystals, 20 to $50 \mu \mathrm{m}$ large (Fig. 7b and d). Many grains, approx. $10 \mu \mathrm{m}$ large, were also observed (Fig. 7c). They were rich in oxygen and presented an average $S$ :Fe ratio of $1.1 \pm 0.1$. They probably correspond to the rozenite or szomolnokite phases formerly identified by Raman and micro XRD.

\subsubsection{Micro imaging of specimen 6889 brownish layer}

Despite several attempts, no information relative to the mineral phases present in the brownish layer of specimen 6889 could be obtained by Raman microspectroscopy mostly because the layer 

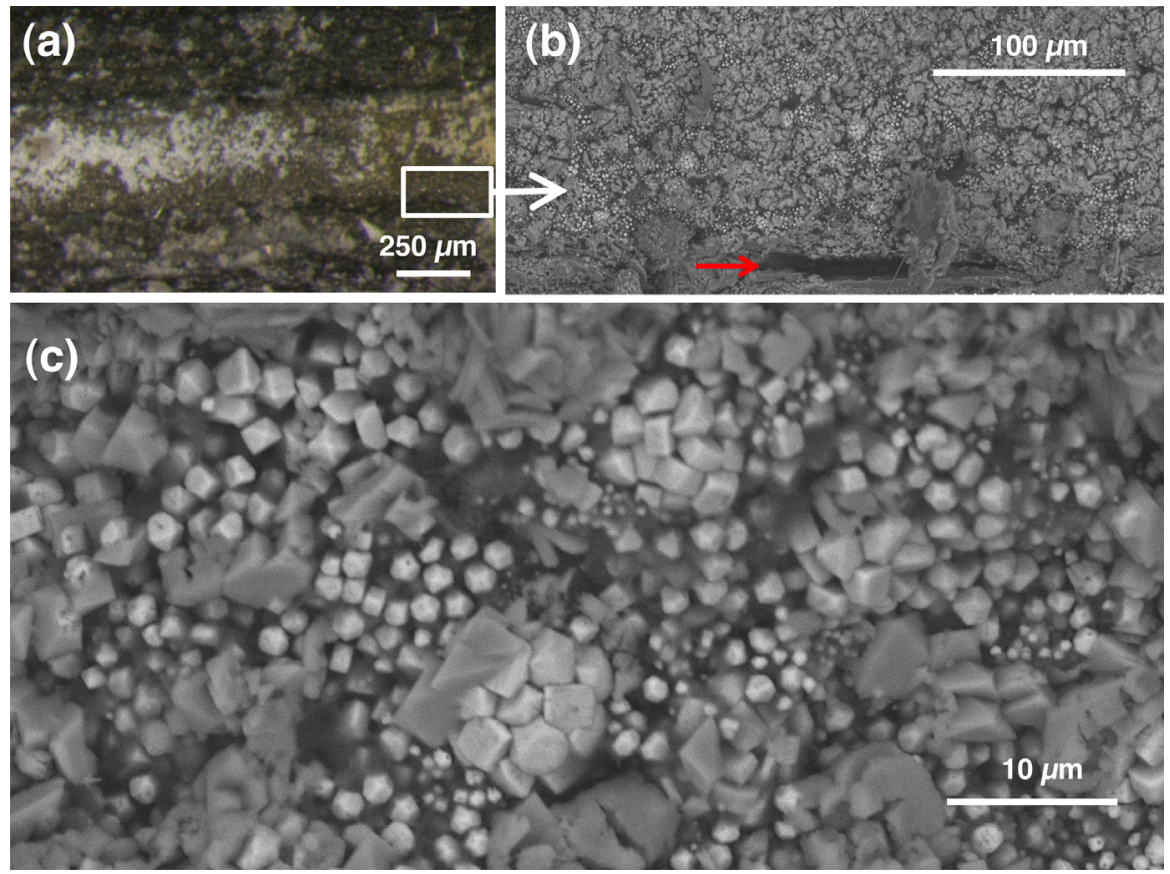

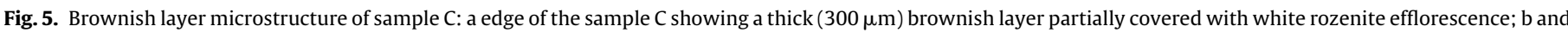

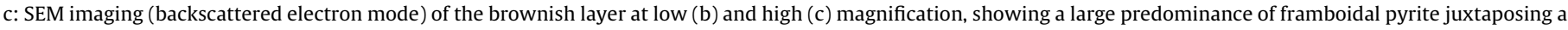
thin (10 to $20 \mu \mathrm{m}$ ) maceral layer (b, red arrow).

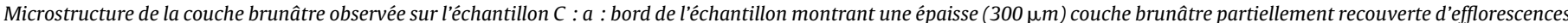

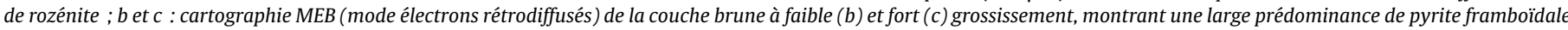
juxtaposant une fine (10 à $20 \mu \mathrm{m}$ ) couche de macéral (b, flèche rouge).

Table 2

Composition of the brown layers observed on B, C, D, Wood and Copro samples identified by Raman microspectroscopy and $\mu$-XRD.

Composition des couches brunâtres observées sur les échantillons B, C, D, Wood et Copro identifiée par microspectroscopie Raman et $\mu$-DRX.

\begin{tabular}{|c|c|c|c|c|}
\hline \multirow[t]{2}{*}{ Sample } & \multirow[t]{2}{*}{ Type of ageing } & \multirow[t]{2}{*}{ Maceral } & \multicolumn{2}{|c|}{ Reduced sulfur species } \\
\hline & & & Framboïdal pyrite & Sulfur \\
\hline B & Ageing $1\left(80 \% \mathrm{RH}, 90^{\circ} \mathrm{C}\right)$ & Yes & Not seen & Not seen \\
\hline C & Ageing $1\left(80 \% \mathrm{RH}, 40^{\circ} \mathrm{C}\right)+1$ year & Yes & Present & Not seen \\
\hline $\mathrm{D}$ & Ageing $1\left(80 \% \mathrm{RH}, 40^{\circ} \mathrm{C}\right)+1$ year & Yes & Present & Not seen \\
\hline Wood & Natural, 18 months & Yes & Present & Present \\
\hline Copro & Natural, 6 months & Yes (vitrinite) & Present & Present \\
\hline
\end{tabular}

contained a high proportion of organic matter ( $\left.\operatorname{signal} \mathrm{sp}^{2}-\mathrm{sp}^{3}\right)$ that fluoresces, thus jeopardizing the signal of other phases.

The brownish layer is however not entirely organic: SEM/EDS elemental analyses evidenced high amounts of iron and sulfur. Moreover, crystals of various dimensions were observed by SEM imaging on the surface of this layer (Fig. 8a). These crystals probably correspond to iron(II) sulfates.

More interesting is the morphology of the organic matter supporting the crystals in which numerous holes were observed. These holes are dispatched in two groups: large ones of dimension ranging 10 to $20 \mu \mathrm{m}$ (Fig. 8a), and small ones of dimension below $2 \mu \mathrm{m}$ (Fig. 8b).

\section{Discussion}

\subsection{Artificial ageing}

\subsubsection{Evaluation of repeatability}

In the present work, ageing experiments corresponding to $80 \%$ RH were duplicated on the Muse FL samples (Table 1, columns 4 to 7). These two campaigns led to the same assessment: crystal growth is boosted by high temperature conditions, whereas mechanical damage was comparable at low or high temperature.
Similar considerations prevailed when ageing is performed at $50 \% \mathrm{RH}$.

In a previous study, artificial ageing was conducted at $50 \% \mathrm{RH}$ on a set of 168 samples distributed in sets of 8 samples and originating from different outcrops of the Autun Basin (excluding Muse FL) (Odin et al., 2014). On this set of samples, crystal growths were more numerous at high temperature than at low temperature, a behavior that was well reproduced in this work. However, in the previous study, it was also observed that mechanical damages were more numerous at low temperature than at high temperature. This second behavior was not reproduced in this work, for a reason that is still not well understood.

\subsubsection{Post artificial ageing evolution of samples}

It was expected that the number of samples concerned with efflorescence increased with artificial ageing duration. Curiously enough this number continues to increase after completion of the artificial ageing process. This can be explained by the fact that post-ageing conditions during storage were significantly drier than ageing conditions, thus favoring evaporation and crystalline growth of sulfate. Sulfates were probably formed during artificial ageing because of high temperature and high humidity conditions. Yet, they remained soluble when the shale was saturated with 

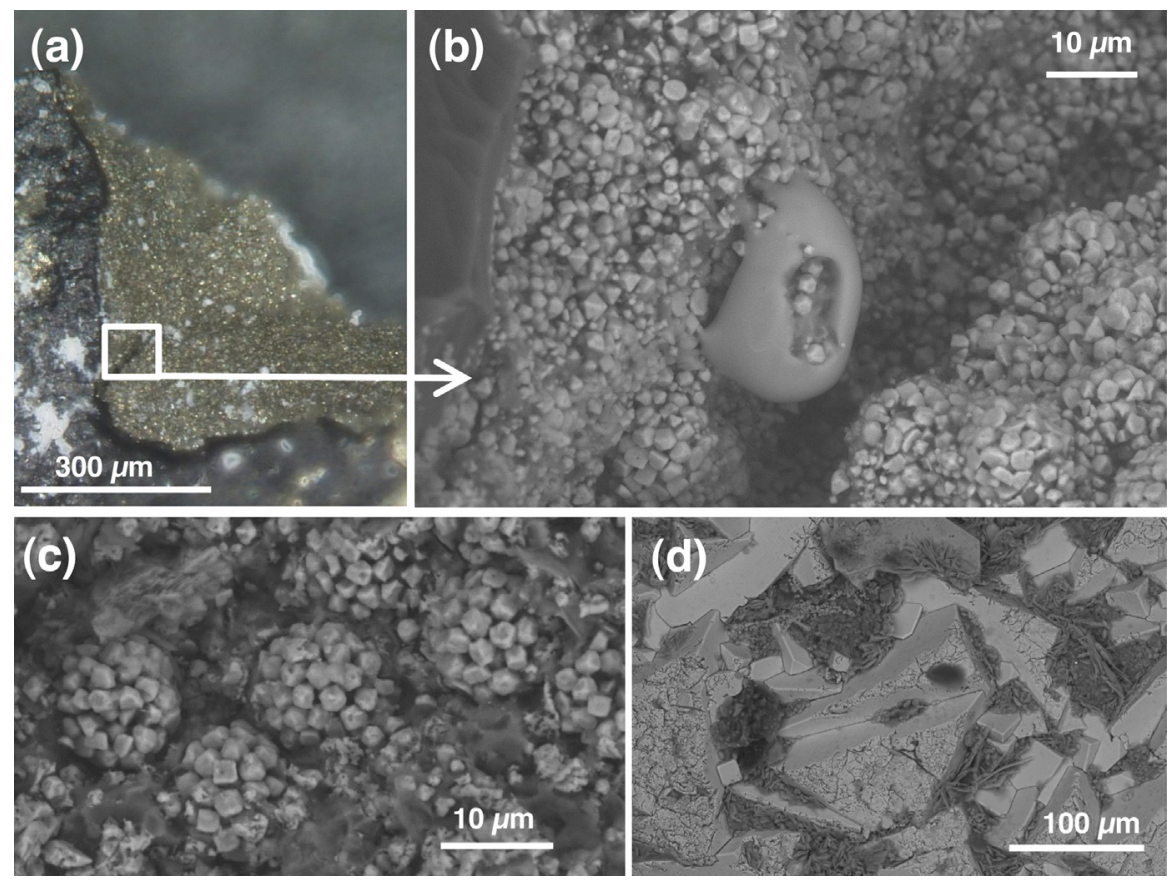

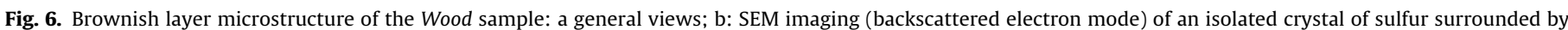

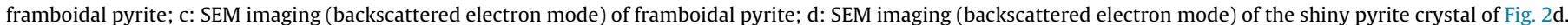

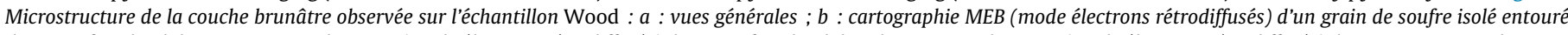

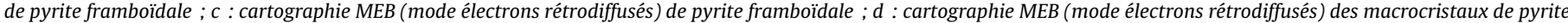
observés Fig. $2 d$.
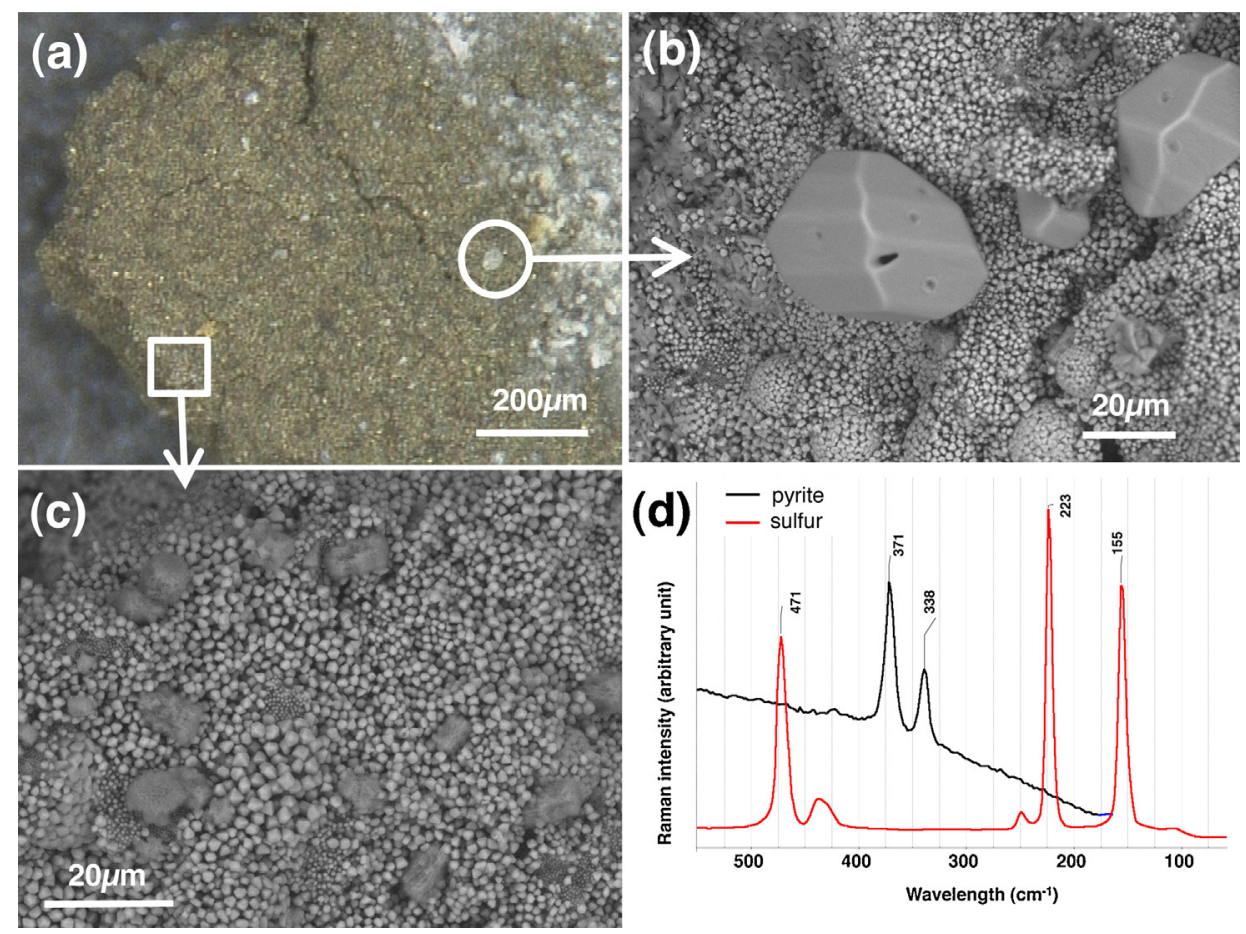

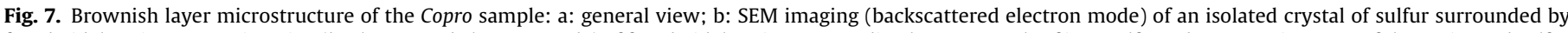

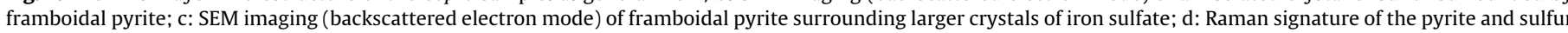
crystals found in the brownish layer.

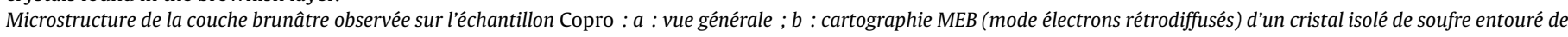

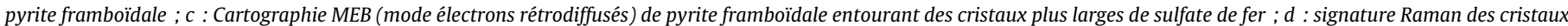
de pyrite et de soufre présents dans la couche brunâtre.

Please cite this article in press as: Odin, G.P., et al., Alterations of fossil-bearing shale (Autun, France; Permian), part III: Framboidal pyrite and sulfur as the main cause of efflorescence. Annales de Paléontologie (2016), http://dx.doi.org/10.1016/j.annpal.2016.01.001 

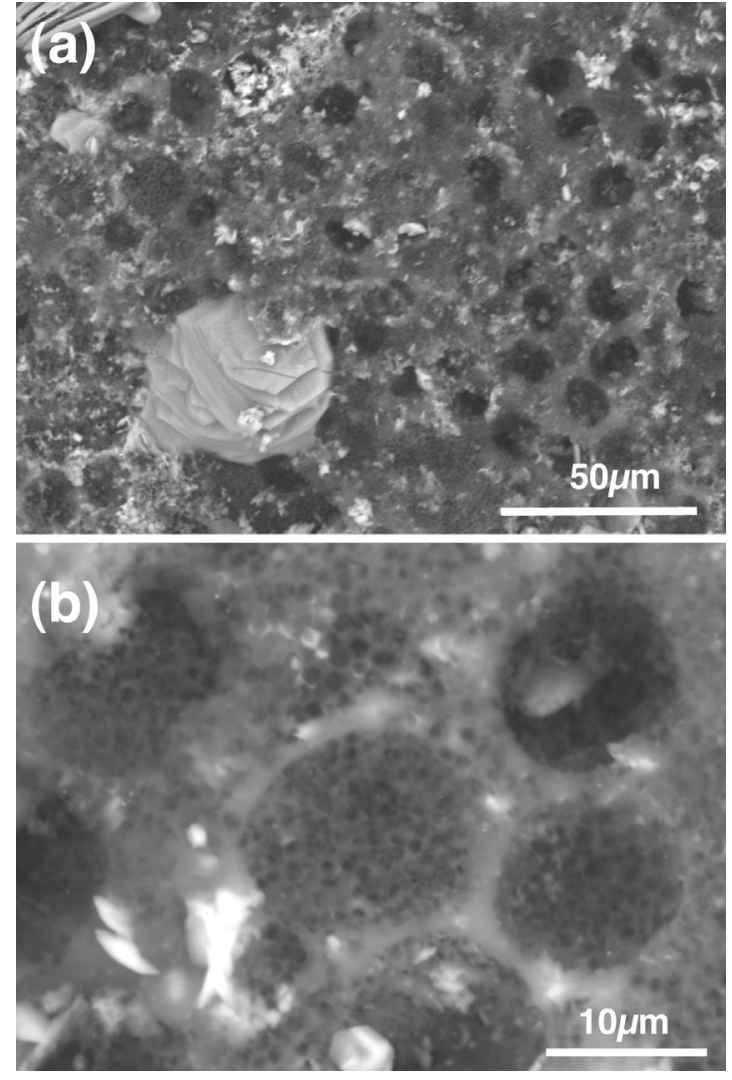

Fig. 8. Brownish layer microstructure of specimen 6889 (MNHN.FR.6889) at low (a) and high (b) magnification.

Microstructure de la couche brunâtre observée sur le spécimen 6889 (MNHN.FR.6889) à faible (a) et fort (b) grossissement.

water. Efflorescence developed when the samples were stored in a drier environment allowing evaporation to take place. This interpretation is consistent with formation of salt efflorescence upon weathering where efflorescence typically develops during dry seasons (Jambor et al., 2000).

\subsection{From laboratory samples to collection specimens: identifying the cause of damages}

\subsubsection{Gypsum efflorescence}

Gypsum was sometimes observed on collection specimens but remains a minor phases of damaging efflorescence (Rouchon et al., 2012). On the Surmoulin samples, large efflorescence of calcium sulfate was growing upon artificial ageing. Yet these samples initially contain a large proportion of calcium carbonate (dolomite) but no pyrite (Odin et al., 2015a). Occurrence of gypsum may, in this case, be explained by oxidation of other sulfur-bearing phases, such as organic sulfides. These latter, may have provoked calcium carbonate dissociation and finally calcium sulfate formation. This point questions the potential reactivity of organic sulfides present in the matrix.

\subsubsection{Iron sulfate efflorescence}

The Copro and Wood samples have many features in common: (i) they are not stable but instead were evolving in ambient conditions during this work (ii) their damage mainly consist in efflorescence of iron(II) sulfates and (iii) they contain layers of maceral matter with brownish deposits composed of framboidal pyrite and larger grains of sulfur (Figs. 6 and 7). The Wood sample additionally shows large crystals of shiny pyrite presenting large crystalline plans (Fig. 6d) and affected by oxidation to a lesser extent. Similar characteristics were found on the artificially aged samples $C$ and D, i.e. iron(II) efflorescence nearby a maceral layer juxtaposing a brownish reactive deposit rich in framboidal pyrite. Yet no sulfur was detected here (Fig. 5). Finally, sample B presents large efflorescence of iron(III) sulfate and gypsum (Fig. 4b) but does not contain reduced sulfur species in its present condition. As this sample was aged at higher temperature $\left(90^{\circ} \mathrm{C}\right)$ than samples $\mathrm{C}$ and $\mathrm{D}\left(40^{\circ} \mathrm{C}\right)$, its degradation is probably more completed meaning that initial iron sulfide species have disappeared.

These observations tend to demonstrate that framboidal pyrite is the main cause of degradation, consistent with its high reactivity (Rosso and Vaughan, 2006). However, micro-analyses were performed a posteriori, ie after iron sulfate growth was observed on the samples. Despite the fact that no other iron sulfide was detected by micro XRD, one cannot totally exclude the former occurrence of an additional highly reactive phase, such as mackinawite, greigite or pyrrhotite that could have been consumed in the first steps of the process.

Isolated grains of sulfur were additionally detected on some samples. They probably come from bacterial activity during pyrite diagenesis (Berner, 1984) since sulfur (and iron monosulfide) are often mentioned as two preliminary phases of sedimentary pyrite formation.

On damaged specimen from the Flouest collection, efflorescence of iron sulfates is mainly located nearby vitrinite layers. These were at first suspected to be the origin of the damage. Yet this hypothesis is not valid: vitrinite mostly contains organic sulfides (Odin et al., 2015b) meaning that it has been poorly affected by oxidation despite exposure to oxygen for more than a century. A more convincing explanation is that vitrinite was originally covered with a thin layer of highly reactive brownish deposit, similar to those depicted above. This deposit is no more visible today because it has been consumed in the oxidation reactions.

Among the Flouest collection, the specimen 6889 is exceptional in that it is composed of a thick layer of vitrinite presenting, in some damaged areas, a matt brownish aspect (Fig. 1). In these areas, sulfur and iron were detected although they were not structured in well-defined crystals. Moreover, several holes were observed by SEM imaging, attesting of a former well-organized structure. Their dimensions match well with those of the framboidal pyrite isolated grains $(<2 \mu \mathrm{m})$ and aggregates $(10-20 \mu \mathrm{m})$ that were observed on the Copro, Wood, C and D samples. All these clues tend to show that the matt brownish layer of the specimen 6889 was formerly covered with a framboidal pyrite layer that has been oxidized as iron sulfate.

\section{Conclusion}

The starting point of this work was the conservation report of shale specimens of the Flouest collection (MNHN). Iron sulfate efflorescence was observed in areas without obvious iron sulfide, thus inquiring the origin of the damage. The intrinsic composition of the shale was investigated in the first two parts of this work, collecting if necessary new material from available outcrops. It appeared that shale from the Autun Basin contained some proportion of iron(II) and iron(III), mostly related to clay minerals. Pyrite was occasionally present, yet in small amounts: it was detected in Muse FL samples but not in Surmoulin samples. These small amounts of pyrite could account for the small crystals of iron(III) sulfates (jarosite) detected in shale matrices, but obviously not for the large efflorescence of iron(II) sulfates observed on MNHN specimens. Vitrinite fragments were noticed in the proximity of this efflorescence, and therefore first suspected to be at the origin of damage. Yet they mostly contained organic sulfides that are not accessible to oxygen because vitrinite is not porous. 
The collection of new shale samples from similar lithographic layers gave a complementary approach: these samples were artificially aged and a great proportion of them showed some dispersed crystals of gypsum. The Surmoulin samples demonstrated that this phase was directly correlated to the reactivity of organic sulfides (i.e. to the reactivity of the matrix). On collection specimens, it is occasionally observed, but does not damage the fossils in the same proportions as iron(II) efflorescence, and is thus considered as minor degradation.

Iron(II) sulfate efflorescence was noticed on three artificially aged samples only (B, C, D). It has been growing nearby brownish deposits that seemed correlated to vitrinite layers. These deposits could easily remain unnoticed by naked eye but were also observed on the Copro and Wood samples that became severely damaged at ambient conditions. They were mainly composed of framboidal pyrite (and occasionally sulfur). Framboidal pyrite, a phase well known for its sensitivity to oxygen and humidity, is thus probably the cause of iron(II) sulfate efflorescence. A similar explanation stands for the damage observed on MNHN specimens.

This work was not only undertaken to explain the degradations observed on fossils that were collected more than a century ago. The knowledge gained in this inquiry will certainly help to improve visual assessment of highly reactive specimens among the currently collected fossils from the outcrop of Muse.

One could a priori conclude that damaged specimens in which pyrite has been entirely transformed to sulfates (such as specimen 6889 ) will be no more reactive in the future. This statement makes sense but should however be moderated as (i) iron sulfate phases may also evolve under hydration/dehydration processes depending on environmental conditions, causing stress in the matrix and (ii) there is no easy way to assess pyrite exhaustion in a specimen as this phase may remain in the inner part of the matrix. It is also advised to store damaged specimen in a temperature and humidity stable environment (as dry as could be to limit pyrite oxidation) and to periodically (ex. every 3-5 years) assess the presence of pyrite and/or the damage using a repeatable macro-picture system.

\section{Disclosure of interest}

The authors declare that they have no competing interest.

\section{Acknowledgements}

This work was supported by a doctoral school grant of the Museum national d'Histoire naturelle (MNHN, Paris, France) and by a postdoctoral grant supported by Sorbonne Université (Convergence project, contract 115218). It also involves a Master thesis supported by the Labex Patrima, Fondation des Sciences du Patrimoine. SEM/EDS measurements were performed on the analytical platform of electronic microscopy, MNHN (Paris, France).

This work was realized in partnership with the Palaeontological Collection Management Unit, Collection Department, MNHN (Paris, France). We also would like to thank MM. Hervé Lelièvre, Olivier Bethoux, Jean Dejax, Dario de Franceschi and Jean Sébastien Steyer for their advice and assistance.

\section{References}

Berner, R.A., 1984. Sedimentary pyrite formation: an update. Geochimica Et Cosmochimica Acta 48, 605-615.

Chandra, A.P., Gerson, A.R., 2010. The mechanisms of pyrite oxidation and leaching: a fundamental perspective. Surface Science Reports 65, 293-315.

Hammersley, A.P., Svensson, S.O., Hanfland, M., Fitch, A.N., Häusermann, D., 1996. Two-dimensional detector software: from real detector to idealised image or two-theta scan. High Pressure Research 14, 235-248.

Heidel, C., Tichomirowa, M., 2011. The isotopic composition of sulfate from anaerobic and low oxygen pyrite oxidation experiments with ferric iron - New insights into oxidation mechanisms. Chemical Geology 281, 305-316.

Jambor, J.L., Nordstrom, D.K., Alpers, C.N., 2000. Metal-sulfate salts from sulfide mineral oxidation. In: Jambor, J.L., Nordstrom, D.K., Alpers, C.N. (Eds.), Sulfate minerals: crystallography, geochemistry, and environmental significance. Mineralogical Society of America, pp. 305-350.

Mernagh, T.P., Trudu, A.G., 1993. A Laser Raman microprobe study of some geologically important sulfide minerals. Chemical Geology 103, 113-127.

Murphy, R., Strongin, D.R., 2009. Surface reactivity of pyrite and related sulfides. Surface Science Reports 64, 1-45.

Odin, G.P., Vanmeert, F., Janssens, K., Lelièvre, H., Mertz, J.-D., Rouchon, V., 2014 Accelerated ageing of shales of palaeontological interest: impact of temperature conditions. Annales de Paléontologie 100, 137-149.

Odin, G.P., Cabaret, T., Mertz, J.D., Menendez, B., Etienne, L., Wattiaux, A., Rouchon, V., 2015a. Alteration of fossil-bearing shale (Autun Basin, France; Permian), part I: characterizing iron speciation and its vulnerability to weathering by combined use of Mössbauer spectroscopy, X-ray diffraction, porosimetry and permeability measurements. Annales de paléontologie 101, 75-85.

Odin, G.P., Vanmeert, F., Farges, F., Vantelon, D., Janssens, K., Rouchon, V., 2015b. Alteration of fossil-bearing shale (Autun, France, Permian), part II: monitoring artificial and natural ageing by combined use of S and Ca K-edge XANES analysis, Rock-Eval pyrolysis and FTIR analysis. Annales de paléontologie 101, 225-239.

Rimstidt, J.D., Vaughan, D.J., 2003. Pyrite oxidation: a state-of-the-art assessment of the reaction mechanism. Geochimica Et Cosmochimica Acta 67, 873-880.

Rosso, K.M., Vaughan, D.J., 2006. Reactivity of sulfide mineral surfaces. In: Vaughan, D.J. (Ed.), Reviews in mineralogy and geochemistry: sulfide mineralogy and geochemistry. Mineralogical Society of America, pp. 557-607.

Rouchon, V., Badet, H., Belhadj, O., Bonnerot, O., Lavédrine, B., Michard, J.G., Miska S., 2012. Raman and FTIR spectroscopy applied to the conservation report of paleontological collections: identification of Raman and FTIR signatures of several iron sulfate species such as ferrinatrite and sideronatrite. Journal of Raman Spectroscopy 43, 1265-1274.

Schoonen, M.A.A., Harrington, A.D., Laffers, R., Strongin, D.R., 2010. Role of hydrogen peroxide and hydroxyl radical in pyrite oxidation by molecular oxygen. Geochimica Et Cosmochimica Acta 74, 4971-4987.

Tuttle, M.L.W., Fahi, J.W., Elliot, J.G., Grauch, R.I., Stillings, L.L., 2014. Contaminants from Cretaceous black shale: I. Natural weathering processes controlling contaminant cycling in Mancos Shale, southwestern United States, with emphasis on salinity and selenium. Applied Geochemistry 46, 57-71. 